DOI: 10.17951/lrp. 2018.37.1.23-39

\author{
KINGA KusZaK \\ Uniwersytet im. Adama Mickiewicza w Poznaniu
}

\title{
DZIECKO PRZEDSZKOLNE: MIĘDZY RZECZYWISTOŚCIĄ, OCZEKIWANIAMI A POTRZEBĄ NIESKRĘPOWANEJ ZABAWY
}

\begin{abstract}
Streszczenie: W artykule dokonano analizy współczesnej neoliberalnej rzeczywistości i praktyk edukacyjnych wobec dziecka przedszkolnego oraz oczekiwań wobec niego, które pozostają w sprzeczności. Rozważania rozpoczęto od zarysowania ogólnej charakterystyki neoliberalizmu jako kompleksu praktyk, dyskursu, światopoglądu, który oddziałuje na wszystkie sfery funkcjonowania współczesnego człowieka. Następnie omówiono neoliberalny dyskurs na temat dzieciństwa. Autorka kreśli następujące obrazy dzieciństwa, które w ramach tego dyskursu są formułowane: dzieciństwo jako inwestycja, dzieciństwo zamknięte w procedurze, dzieciństwo braku czasu, dzieciństwo wirtualne, dzieciństwo komercyjne. W sprzeczności do wymienionych dyskursów i wynikających z nich praktyk pozostają oczekiwania wobec dziecka. Zwrócono uwagę na następujące oczekiwania, którym dziecko powinno sprostać: umiejętności zarządzania własnym czasem, sprawstwa i niezależności, skupienia i uważności, selekcji ofert i dokonywania wyboru. Autorka podejmuje próbę spojrzenia na zabawę jako formę inwestycji w dzieciństwo dobrej jakości. Zwraca uwagę na wybrane aspekty zabawy, spontaniczne, które pozwalają jednostce ukształtować cechy i rozwinąć umiejętności pożądane przez współczesne społeczeństwo. W części końcowej sformułowano wskazówki przydatne w praktyce edukacyjnej, wśród których autorka wskazuje na możliwości tworzenia sytuacji, w których dziecko będzie się bawić, towarzyszenia mu podczas zabawy, współtworzenia $\mathrm{z}$ dzieckiem zabawy itp. Zwraca uwagę na rolę dorosłego w stwarzaniu dziecku okazji do bawienia się bez pośpiechu i presji czasu.
\end{abstract}

Słowa kluczowe: neoliberalizm, dziecko przedszkolne, oczekiwania wobec dziecka, zabawa

\section{WPROWADZENIE}

Neoliberalizm jako kompleks praktyk (doktryna społeczno-ekonomiczna, dyskurs, światopogląd) (Rutkowiak 2012, s. 127), które są „zorganizowane wokół pewnego 
wyobrażenia marketu jako podstawy uniwersalizacji opartej na rynkowych relacjach społecznych z towarzyszącą im penetracją prawie każdego aspektu naszego życia, dyskursu z praktyką utowarowienia, akumulacji kapitału, pomnażania zysków" (Potulicka 2014, s. 9) - jak podkreślają Alfredo Saad-Filho i Deborah Johnston „wywiera silne piętno na życiu miliardów ludzi na wszystkich kontynentach, w różnych sferach, jak: ekonomia, polityka, stosunki międzynarodowe, ideologia, kultura itp." (tamże). Przekształca życie jednostek i całych grup społecznych w nieustanną pogoń za sukcesem, którego wyznacznikami są dobra materialne, ich konsumpcja, prestiż i wysoka pozycja społeczna. Zaś symbolem nowoczesnej wolności stał się aktualnie pieniądz; jak zauważa Danuta Michałowska, dla jednostki „posiadanie pieniądza stanowi nowoczesny wymiar doświadczania wolności” (Michałowska 2013, s. 52). W tym aspekcie utożsamia się neoliberalizm z konsumpcjonizmem, na co zwraca uwagę np. Eugenia Potulicka (Edukacja przeciw neoliberalnym „wartościom” i polityce oświatowej), która podkreśla, iż neoliberalizm to strategia zarządzania globalnym światem, gdzie wszelkie prawa człowieka sprowadza się do prawa własności i nieustannego doświadczania przyjemności, a pogoń za nimi „prowadzi do realizowania dziwacznych, czy »wyuzdanych marzeń«, dzięki którym człowiek może poczuć się nie tyle tym, kim naprawdę jest, lecz tym, kim mu się za pomocą marketingu i reklamy, wmawia, że może być” (Michałowska 2013, s. 75). Jednostka dążąca do sprostania temu zewnętrznemu przymusowi koncentruje swoją uwagę i działania na budowaniu własnej tożsamości, poświęca czas wartościom i celom związanym z samorealizacją (Lewartowska-Zychowicz 2014, s. 148), przy czym zarówno wartości, cele, jak i sposoby ich osiągania są zazwyczaj oferowane jednostce $\mathrm{z}$ zewnątrz w ramach tzw. kultury popularnej i kultury wizualnej. Agnieszka Cybal-Michalska, dokonując analizy funkcjonowania społeczeństwa sukcesu, dodaje, że stało się ono „terenem przejawiania inicjatyw jednostek, przestrzenią bez limitu tworzenia, bankiem licznych możliwości, szans i perspektyw dostępnych każdemu, kto ukierunkuje się na ich dostępność" (Cybal-Michalska 2013, s. 20). Z tej bogatej i zróżnicowanej oferty każdy ma prawo wyboru drogi, która pozwala na samorealizację. Wybór jest trudny, gdyż rzeczywistość podsuwa jednostce kolejne atrakcyjne obrazy, które odrywają od wcześniej przyjętego celu, rozpraszają uwagę itp. Trudno zatem nie zgodzić się ze spostrzeżeniem Bogusława Śliwerskiego, który pisze, iż „kiedy komuś się nie powodzi, kiedy pozostaje w tyle, chciałoby się powiedzieć: on sam tak chciał, sam jest temu winien, nie wykorzystał swoich szans" (Śliwerski 2005, s. 364). Współczesność bogata w oferty i możliwości stawia współczesnego człowieka wobec szeregu wyzwań wymagających od niego dysponowania następującymi cechami: koncentracja na celu (celach), wytrwałość, gotowość do ciężkiej pracy, dyspozycyjność, posłuszeństwo, lojalność, indywidualna odpowiedzialność, poczucie wewnętrznego sprawstwa, efektywność (wydajność), 
przedsiębiorczość, umiejętność zarządzania własnym kapitałem (jego zdobywania, pomnażania, zabezpieczania), umiejętność pracy w zespole.

\section{SPOŁECZEŃSTWO NEOLIBERALNE \\ WOBEC DZIECKA PRZEDSZKOLNEGO - CODZIENNOŚĆ I OCZEKIWANIA}

Neoliberalizm zdominował każdy niemal obszar życia współczesnego człowieka, wkroczył też w przestrzeń edukacji na wszystkich poziomach i wyznacza codzienne praktyki, których podmiotem (a często obiektem) jest dziecko. Jak pisze Potulicka, koncepcja neoliberalnej edukacji została opracowana przez ekonomistów, świat biznesu i polityków skupionych w światowych organizacjach, takich jak: MFW, BŚ, WHO, OECD (Potulicka, Edukacja przeciw neoliberalnym „wartościom” i polityce oświatowej), bez udziału pedagogów. To polityka, biznes i ekonomia decydują o kształcie edukacji, jej celach, zadaniach itp. Danuta Waloszek podkreśla, iż XXI wiek to dzieciństwo „sprzedane, zawłaszczone przez korporacje, producentów, polityków" (Waloszek 2006, s. 35). Wspomniana autorka zauważa też, że dzieciństwo jest obiektem manipulacji. Dziecko traktowane jest jako jednostka pasywna, funkcjonująca w świecie zaprojektowanym i dowolnie zmienianym przez dorosłych, gdyż dopiero przygotowuje się do rzeczywistego procesu uczenia się, który rozpocznie się w szkole (Grochowalska 2015, s. 94). Jest zatem jednostką nie w pełni wartościową, bo dopiero „stającą się”. Astrid Męczkowska-Christansen pisze wręcz o „alienacji dzieciństwa” i zwraca uwagę, że „dzieciństwo stanowi »inność", z którą obchodzenie się wymaga specjalnych postaw, odrębnego języka, »nienaturalności« przejawianych w międzyludzkich kontaktach" (Męczkowska-Christiansen 2011, s. 185-186). Dziecińst wo trzeba zatem zorganizować, zainwestować w wartościową przyszłość człowieka. Jest to możliwe przez zaprojektowanie jego stylu życia, w tym ściśle określnej ścieżki edukacyjnej, sposobu spędzania wolnego czasu, dobór rówieśników, przyjaciół itp. Dzieciństwo zostało więc zamknięte $\mathrm{w}$ procedurze drogi do sukcesu, towarzyszy mu presja zorientowana na osiągnięcia, nieustanny brak czasu bliskich dla dziecka i czasu dziecka na bycie dzieckiem. Stawia się przed nim zadania i oczekiwania, którym ze względu na specyfikę rozwojową nie jest w stanie sprostać. Alternatywą dla realnego życia, które wywołuje frustracje zarówno dorosłych, jak i dzieci, staje się aktywność w świecie nierzeczywistym, a samo dziecko osadzone zostaje w rolach klienta i konsumenta, które dają namiastkę spełnienia, chwilowego sukcesu, gdyż - jak podkreśla Zbyszko Melosik - „konsument ma dążyć do swojego szczęścia bez najmniejszego wahania i dążyć do maksimum satysfakcji” (Melosik 2013, 
s. 161). Zasygnalizowane tu praktyki wobec współczesnego dziecka przedszkolnego przedstawię zatem szerszej w kolejnych rozważaniach, ukazując jednocześnie oczekiwania, jakie formułuje wobec niego społeczeństwo.

\section{INWESTOWANIE W DZIECI - OCZEKIWANIE OD DZIECKA, ŻE BĘDZIE „DOBRĄ INWESTYCJĄ” I BĘDZIE SZCZĘŚLIWE}

Współczesne neoliberalne społeczeństwo oczekuje „dobrych dzieci”, czyli takich, które są zdrowe, sprawne, inteligentne, uzdolnione, harmonijnie rozwijające się itp. Małgorzata Karwowska-Struczyk podkreśla, iż „tylko takie są chciane przez rodzinę, wspólnotę, naród i państwo” (Karwowska-Struczyk 2007, s. 105). „Dobre dzieci" umożliwiają opiekunom urzeczywistnienie ich wizji dobrego rodzicielstwa, rodzicielstwa sukcesu. Opiekunowie starannie projektują więc ścieżki życiowe dzieci. Od momentu narodzin (a często wcześniej) rodzice podejmują zobowiązania „inwestycyjne”. Gotowi są ponieść wysokie koszty związane z tworzeniem dzieciom „dzieciństwa najlepszej jakości” w różnych sferach: od opieki medycznej począwszy, przez edukację, po ofertę zajęć dodatkowych itp. Wyniki badań wskazują, iż 59\% dzieci w wieku przedszkolnym i aż 78\% dzieci z klas I-III uczestniczy w (zazwyczaj odpłatnych) zajęciach dodatkowych (Łaciak 2011, s. 84). Pojawia się więc kategoria drogich dzieci, kosztownych dzieci. Waldemar Segiet podaje koszty wychowania dzieci na najwyższym poziomie: opiekunka ok. 31 tys., nauka od przedszkola do końca studiów ok. 260 tys., zajęcia dodatkowe ok. 130 tys., wakacje nastolatka ok. 65 tys. (Segiet 2011, s. 44). Im wyższa pozycja rodziny w strukturze społecznej, tym większe są jej możliwości inwestowania w dziecko i tym większy udział rodziców w organizowaniu dzieciństwa wypełnionego rozmaitymi aktywnościami, które dorośli uważają za wartościowe. Inwestycja, którą podejmują opiekunowie, powinna w konsekwencji przynieść zysk w postaci sukcesów szkolnych, sukcesów w konkursach, olimpiadach, w sporcie, sztuce itp. W przyszłości dziecko-inwestycja ma uzyskać wysoką pozycję zawodową, ekonomiczną, społeczną, towarzyską itp. Ten fakt ostatecznie potwierdzi wartość poczynionych przez rodziców wysiłków. Dostępne w literaturze wyniki badań na temat percepcji sukcesu własnego i dzieci przez przedstawicieli współczesnej klasy średniej wskazują, iż wyznacznikiem sukcesu w tej grupie społecznej, obok aktywności zawodowej, jest udane życie rodzinne oraz osiągnięcia edukacyjne (Nyczaj-Drąg 2015). Od dziecka oczekuje się zatem zaangażowania w proces stawiania się „dzieckiem sukcesu”, wewnętrznej dyscypliny związanej z koniecznością sprostania wymaganiom, radzenia sobie z trudnościami natury zewnętrznej, trudnościami wewnętrznymi, szybkiego podnoszenia się po niepowodzeniach, radzenia sobie ze stresem itp. Musi być 
przy tym szczęśliwe, bo przecież opiekunowie pragną jego dobra, sami gotowi są zrezygnować z zaspokojenia własnych potrzeb, by dziecko osiągnęło więcej.

\section{DZIECIŃSTWO ZAMKNIĘTE W PROCEDURZE - OCZEKIWANIE SPRAWSTWA I NIEZALEŻNOŚCI}

Z praktyki pierwszej wynika kolejna - dzieciństwa zamkniętego w procedurze regulaminów, diagnoz, pomiarów, ocen, monitorowania zmian, ewaluacji, w której dorosły (szczególnie nauczyciel) „ma być zaprogramowanym i nadzorowanym urzędnikiem, bez szans na realną promocję społecznej podmiotowości kolejnych pokoleń" (Śliwerski 2014, s. 20). Procedura polega na „wpasowanie dziecka we wzorzec funkcjonowania zgodny z przyjętym przez dorosłych przepisem (przepisami) roli, zadań i sposobów ich realizacji” (tamże, s. 14). Jak pisze Bogusław Śliwierski, o sprawach dzieci „stanowi się bez ich i rzeczywistego udziału (o nich bez nich), lekceważąc także najważniejszych rzeczników ich interesów i potrzeb, jakimi są rodzice” (tamże, s. 14). Najmłodszy staje się „dzieckiem organizacji”, które

rozpoznając siebie, swoje motywy i pragnienia, wytwarzając znaczące punkty swojej biografii [...], identyfikuje się z celami i logiką funkcjonowania dla instytucji poddaje się obowiązującym w niej rytuałów, rezygnuje z indywidualnej kreatywności na rzecz kolektywnych wartości, działań i znaczeń nadawanych rzeczywistości (Klus-Stańska 2011, s. 21).

Jak podkreśla Dorota Klus-Stańska, status zarówno dzieci, jak i nauczycieli zostaje obniżony i sprowadzony do realizacji oczekiwań resortu (Klus-Stańska 2011, s. 22). Dziecko odgrywa więc narzuconą mu rolę zgodnie z przepisem określonym w procedurze. Kiedy próbuje zachowywać się naturalnie i spontanicznie, mierzy się z szeregiem zakazów, wynikających z ustalonych przez dorosłych zasad, słyszy więc uwagi: „Pospiesz się”, „Nie krzycz”, „Nie biegaj”, „Nie baw się, teraz nie ma czasu na zabawę”, „Nie tak, zrób tak jak mówiłem (mówiłam)”, którym w konsekwencji musi się podporządkować i wywiązać się z określonych nałożonych na nie powinności: w sytuacjach codziennych, względem innych ludzi, dotyczących własnego rozwoju, cech i zachowań (Olczak 2014, s. 49-53). Dzieciństwo ujęte w ramy procedury to także dzieciństwo nieustannie diagnozowane i rozliczane $\mathrm{z}$ realizacji kolejnych zaleceń. Umyka powszechnej uwadze, co słusznie podkreśla Agnieszka Olczak, iż „dla społeczeństwa i jego rozwoju potrzebni są ludzie wolni, samodzielni w myśleniu i działaniu” (Olczak 2014, s. 43), a nie tylko mierzalni i rozliczalni. 


\section{BRAK CZASU DLA DZIECKA I BRAK CZASU DZIECKA - OCZEKIWANIE UMIEJĘTNOŚCI ORGANIZACJI WŁASNEGO CZASU PRZEZ JEDNOSTKE}

Współczesny człowiek nie ma czasu, ,jest w nieustannym procesie czasochłonnego śledzenia pseudoinformacji medialnych czy nowości w produktach rynkowych oraz usługach. Pośpiech i ciągły niepokój towarzyszą mu każdego dnia" (Michałowska 2013, s. 94). Maria Braun-Gałkowska podkreśla, że „wszyscy na skutek tego pośpiechu jesteśmy coraz bardziej zmęczeni i zdenerwowani; zachowanie staje się chaotyczne, a kontakty z ludźmi powierzchowne" (Braun-Gałkowska 2008, s. 335). W takiej rzeczywistości kapitałem, który rodzice mogą oferować swoim dzieciom, jest czas. Czas spędzony z dzieckiem staje się dla rodziców szczególnie cenny i jawi się jako wyznacznik bycia dobrym rodzicem (Maciejewska-Mroczek 2012, s. 67). Warto nadmienić, że budżet czasu wygląda inaczej u osób reprezentujących różne kategorie i grupy społeczne. Inaczej wygląda budżet czasu biznesmena, inaczej artysty, a jeszcze inaczej naukowca. Niezależnie od tego faktu badania sugerują, że co piąty rodzic przyznaje, iż trudno mu w codziennym zabieganiu wygospodarować czas dla dziecka. Większość rodziców twierdzi, że może sobie pozwolić jedynie na wspólny niedzielny obiad, wyjście do kościoła lub zakupy (Łaciak 2011, s. 81). Opiekunowie starają się więc spędzić nieliczne godziny, które w budżecie czasu mogą wygospodarować dla dzieci, wspólnie, w sposób jak najbardziej atrakcyjny, najczęściej wybierając aktywność rozrywkowo-rekreacyjną (Łaciak 2011, s. 81). Warto nadmienić, że badania wskazują, iż pracujące matki spędzają z dziećmi coraz więcej czasu. Tomasz Szlendak, opisując tę kwestię, podkreśla, iż aktualnie rodzice znaczną część pracy zawodowej przenoszą do domu, co wydłuża czas spędzany $\mathrm{z}$ dzieckiem. Zdaniem tego autora praca $\mathrm{w}$ domu oznacza dzisiaj tak naprawdę opiekę nad dzieckiem (Szlendak 2001, s. 441). Opiekunowie poszukują jednocześnie sposobów na lepszą organizację czasu zawodowego i tego przeznaczonego dla rodziny. Wyrazem tych poszukiwań jest sięganie po poradniki na temat efektywnego zarządzania czasem, np. Jak efektywnie zarzadzać czasem $w$ rodzinie, Jak rodzice moga usprawnić swoje obowiązki, by mieć więcej czasu dla siebie i dzieci? Dzięki wykorzystaniu zaproponowanych tam rozwiązań dorośli próbują organizować czas własny i czas, którym dysponuje dziecko. Oczekują, że dzięki temu dziecko wkrótce samo zacznie dobrze zarządzać swoim czasem. 


\section{WIRTUALNE DZIECIŃSTWO \\ W KILKU PRZESTRZENIACH JEDNOCZEŚNIE - OCZEKIWANIA OD DZIECKA SKUPIENIA NA JEDNEJ CZYNNOŚCI I UWAŻNOŚCI}

Badania nad tzw. syndromem dziecinnego pokoju obrazują, że współczesne dziecko co prawda ma swoją przestrzeń - pokój wypełniony zabawkami, grami, sprzętem multimedialnym, równocześnie jednak pozbawione zostaje ważnych dla jego rozwoju społeczno-emocjonalnego bezpośrednich i bliskich kontaktów z innymi ludźmi. Daniel Goleman zauważa, że „dzisiejsze dzieci wzrastają w nowej rzeczywistości - jeszcze nigdy nie było tak, żeby ludzie tak bardzo zwracali uwagę na maszyny, a tak mało na inne osoby" (Goleman 2014, s. 16). Jadwiga Izdebska dodaje, że współczesne dzieciństwo

jest to dzieciństwo bardziej indywidualne, domowe, prywatne przy urządzeniach elektronicznych, z porozumiewaniem się za pomocą klawiatury komputera, z dominacją relacji o charakterze pośrednim z wyraźną reedukacją i ograniczeniem kontaktów bezpośrednich między ludźmi (Izdebska 2007, s. 24).

Dziecko spędza czas wśród atrakcyjnych, kosztownych przedmiotów, za zamkniętymi drzwiami swojego pokoju, w świecie oddzielonym od świata dorosłych (Brzezińska, Janiszewska-Rain 2005, s. 17). Przestrzeń pozbawioną udziału realnych osób, autentycznych sytuacji i zdarzeń wypełnia barwna przestrzeń fikcyjnych osób i zdarzeń tworzących rzeczywistość łatwą w odbiorze, wypełnioną atrakcyjnymi bodźcami (docierającymi różnymi kanałami) przyciągającymi uwagę, angażującą emocjonalnie. Dziecko przebywa więc w rzeczywistości wymagającej natychmiastowego reagowania, dużej ruchliwości w różnych nierealnych światach, podzielności uwagi, koncentrowania jej na wykonywaniu kilku czynności jednocześnie. W tej rzeczywistości ma możliwość przerwania działania i powrócenia do niego w dogodnym momencie, może też zupełnie zrezygnować z działania. Od tego samego dziecka w rzeczywistości pozawirtualnej oczekuje się uważności, wytrwałego skupienia na jednej czynności, bez możliwości jej przerywania, by zająć się czymś innym, np. uważnego słuchania czytanego przez kogoś monotonnym głosem tekstu, wykonania zadania do końca (np. wyklejanki składającej się z wielu elementów, które muszą zostać ściśle do siebie dopasowane) itp. 


\section{KOMERCJALIZACJA DZIECIŃSTWA - OCZEKIWANIE OD DZIECKA UMIEJĘTNOŚCI SELEKCJI OFERT I DOKONYWANIA WYBORU}

Współczesne dziecko postrzegane jest jako aktualny i przyszły klient. J. McNeal wyróżnia trzy sposoby udziału dzieci w rynku konsumenckim: konsumpcję bezpośrednią przez samodzielne zakupy; konsumpcję pośrednią, kiedy dzieci wywierają wpływ na to, co kupują rodzice; konsumpcję przyszłą, która dokonuje się na skutek przywiązania jednostek w okresie dzieciństwa do określonych marek lub produktów (Łaciak2011, s. 92). Producenci podejmują szeroko zakrojone działania związane z tym, by zadbać o zaspakajanie materialnych potrzeb najmłodszych, ale też by je kreować i rozwijać pozytywne skojarzenia związane z konsumowaniem i funkcjonowaniem w roli klienta. Badania wskazują, iż np. programy telewizyjne dla najmłodszych odbiorców „budują świat funkcjonujący na zasadzie zamkniętego obiegu", w którym prezentowane są gry, reklamy produktów, a nagrodami są medialne artefakty. Takie programy są przedłużeniem reklamy całej gamy produktów, których odbiorcami są najmłodsi konsumenci (Buckingham 2008, s. 160-161). Na wspomniany fakt wskazuje poniższa wypowiedź zanotowana przez Magdalenę Chmurską i Beatą Łaciak (2013, s. 150):

myślimy o tym, że przyjeżdżają do nas rodziny z dziećmi [...]. Wiemy, że to są nasi potencjalni klienci tak naprawdę, więc im bardziej się przygotowujemy na ich przyjście tutaj, im bardziej oni polubią sklep, czyli za parę lat to będą nasi klienci, którzy będą tak naprawdę kupowali u nas i namawiali do tego, żeby przyjść do nas.

Współczesność kształtuje więc jednostki, którym „wpaja się nawyk wydawania pieniędzy na wszelkie zachcianki i nowości, jednostki łaknące nowych przeżyć, emocjonalne i hedonistyczne, czerpiące radość z konsumpcji” (Kantor 2013, s. 24). W rzeczywistości pełnej pokus i możliwości łatwego ich zaspokajania dziecko spotyka się ze sprzecznymi oczekiwaniami: $z$ jednej strony ulegania tym pokusom i oddawania się przyjemności nabywania dóbr, z drugiej strony umiejętności selekcjonowania dostępnych ofert, powściągania pragnień i dokonywania wyborów.

\section{ZABAWA JAKO FORMA „INWESTYCJI” W DZIECKO}

Pośpiech, brak czasu, dążenie do łatwej i szybkiej rozrywki, wszechogarniająca komercjalizacja życia, hiperkonsumpcja i nieustanna jej racjonalizacja „odzierają współczesny świat z pierwotnej niezwykłości” (Świetlik 2009, s. 257), odwracają dziecko od świata zabawy. Danuta Waloszek, dokonując analizy rzeczywistości, 
formułuje refleksję, iż „dzieci przestały się bawić, uczyć się - są zabawiane (przez aktorów, magików), poprawiane (przez logopedów, korektorów, trenerów), mierzone, czy się nadają do szkoły, elektronicznie rejestrowane do przedszkola" (Waloszek 2009a, s. 139). Z różnych stron płyną skargi, że współczesne dzieci zgubiły gdzieś, zatraciły spontaniczność, naturalny zapał działania, kreowania i przetwarzania rzeczywistości i umiejętność zabawy. Bronisława Dymara stwierdziła wręcz, że trzeba „wskrzesić żywioł i radość zabawy” (Dymara 2009, s. 36). Tymczasem zabawa jest formą inwestycji w dzieciństwo dobrej jakości (i tak powinna być postrzegana). Na poparcie tej tezy można przywołać słowa Donalda Wooda Winnicotta, który zauważył, iż „kiedy dasz dziecku czas na całkowite doświadczenia i kiedy sam (sama) będziesz w nich uczestniczyć, to stopniowo zbudujesz podstawy jego umiejętności przeżywania różnego rodzaju doświadczeń bez pośpiechu i zdenerwowania" (Winnicot 1993, s. 79). Czas na zabawę bez pośpiechu i zdenerwowania wywołanego koniecznością jej przerwania w momencie, gdy dziecko nie jest jeszcze gotowe na jej zakończenie, gdy potrzebuje się bawić, sprzyja rozwijaniu jego różnych dyspozycji. Wśród nich ważne miejsce zajmuje poczucie sprawstwa, które jest ważną i cenioną dyspozycją we współczesnym świecie. Sprawstwo rozumiem tu jako zawiadywanie własnymi czynnościami i podejmowanie odpowiedzialności za podjęte i wykonane zadania (Kopaczyńska 2010, s. 101). Do wyznaczników poczucia sprawstwa zalicza się doświadczanie podmiotowej kontroli, które obejmuje:

1. motywację do podejmowania działań,

2. poczucie wolności wyboru,

3. percepcję wpływu na rzeczywistość,

4. poczucie własnej skuteczności działania (posiadanej kompetencji) (Kopaczyńska 2010, s.102-103).

Dziecięcą zabawę jako inwestycję można rozpatrywać, rozważając jej różne aspekty opisane poniżej.

\section{ASPEKT PIERWSZY - SAMOKONTROLA}

Dziecko z uwagą obserwuje świat, dostrzega i zapamiętuje sytuacje, w których samo uczestniczy lub tylko jest świadkiem. Doświadcza przy tym, jak pisał Lew Wygotski, wielu niezrealizowanych tendencji i pragnień wynikających z bycia w tym obserwowanym świecie. Cechą rozwojową dziecka w okresie średniego dzieciństwa jest utrzymująca się jeszcze z wcześniejszego etapu życia tendencja do natychmiastowego zaspokojenia pojawiających się potrzeb. Te potrzeby wynikają $\mathrm{z}$ bycia w świecie, ale są też przez ten świat rozbudzane i sztucznie kreowane. Dziecko potrafi jednak powściągnąć już wiele z tych pojawiających się pragnień 
(nie zachowuje się więc jak dwulatek, który widząc atrakcyjny przedmiot, obiekt, czy ciekawą sytuację, musi natychmiast zaspokoić potrzebę posiadania, włączenia się w działania, bycia tu i teraz). Potrzeby i pragnienia jednak nie przemijają, ale - mówiąc językiem Lwa Wygotskiego - „zostają uogólnione”, a dziecko może odroczyć ich realizację i uzewnętrznić po jakimś czasie np. w formie zabawy. Aby poradzić sobie z kumulującymi się pragnieniami, dziecko potrzebuje swobody dającej możliwość ich uzewnętrzniania w sposób niebezpośredni. Sprzyja temu rozwijająca się wyobraźnia, która pozwala na „oddzielenie pola wizualnego od pola sensu" (Wygotski 2002, s. 145). To dzięki możliwości przedstawienia sobie w umyśle przedmiot, osoba, sytuacja w trakcie dziecięcej zabawy może stać się czymś zupełnie innym, tym, co dziecko chce i potrafi sobie przedstawić. Bawiące się dziecko może zatem kontrolować swoje zachowania tak, aby były one zgodne $\mathrm{z}$ wyobrażoną sytuacją.

\section{ASPEKT DRUGI - REGUŁY I RAMY DZIAŁANIA}

Zabawa daje dziecku wolność wyobrażania sobie. Wyobrażanie sobie podczas zabawy nie jest jednak pozbawione reguł. To właśnie w trakcie zabawy dziecko uczy się postępowania zgodnie z regułami i wewnętrznej dyscypliny. To jest drugi ważny aspekt zabawy, na który chcę zwrócić uwagę. Dziecko potrzebuje ram, w których jego zabawa będzie zamknięta, i dyscypliny, zgodnie z którą będzie realizowana. Takie ramy i dyscyplinę samo sobie narzuca. Wyobraziwszy sobie, że otrzymało list od tajemniczego nadawcy, który ukrył skarb na wyspie, wchodzi $\mathrm{w}$ rolę poszukiwacza tego skarbu, musi zatem postępować zgodnie z regułami odpowiednimi dla poszukiwania skarbu. Konieczne jest zaopatrzenie się w akcesoria niezbędne do podjęcia czynności poszukiwawczych. Muszą one spełniać kryteria pozwalające na przeprowadzenie poszukiwań. Przedmiotom i obiektom trzeba więc przypisać funkcje i określić zasady ich wykorzystania. Czyniąc to, dziecko korzysta ze swojej wiedzy i doświadczenia. Podejmuje i realizuje zabawę tak, jak wie i potrafi. Bawiąc się, przetwarza to, co może dostrzec i zaobserwować w swoim otoczeniu, wybierając te jego elementy, które pozwalają mu bawić się zgodnie z przyjętą regułą (regułami).

\section{ASPEKT TRZECI - MOŻLIWOŚĆ INTERPRETACJI ŚWIATA}

W trakcie zabawy dziecko nie zmienia świata, ale „dokonuje jego indywidualnej interpretacji” (Kuszak 2005, s. 9). Doświadcza swobody jego kreowania. Warto 
nadmienić, że zabawa każdego dziecka przebiega inaczej, realizowana jest też inaczej za każdym razem, kiedy dziecko ją podejmie nawet, jeżeli dany wątek pojawia się po raz kolejny. Zaś same reguły, które za każdym razem tworzy, wynikają z przebiegu zabawy, nie są formułowane na wstępie, lecz elastycznie zmieniają się w trakcie (tak powstała reguła „kto dotknie ziemi, ten nie żyje”, która jest wyrazem spontaniczności wolności bawiącego się dziecka).

\section{ASPEKT CZWARTY - RZECZYWISTOŚĆ REALNA I WYOBRAŻONA}

Bawiące się dziecko postępuje zgodnie ze specyfiką przyjętej roli i działa na serio, ale zdaje sobie jednocześnie sprawę z umowności i nierealności świata zabawy. Uchwycenie symbolicznego aspektu zabawy pozwala dzieciom działać w dwóch rzeczywistościach jednocześnie: realnej i wynikającej z przyjętej konwencji zabawy: „Słuchajcie, zróbmy tak. Poczekajcie, tak będzie lepiej. Ja się tak nie bawię” (Korczak 2010, s. 111). Tę drugą mogą dowolnie kreować, modyfikować, zmieniać lub przerywać wówczas, gdy pojawia się zmęczenie, negatywne lub nadmierne emocje, gdy dany motyw się „wyczerpie”. Można ją podejmować po przerwie i realizować w zupełnie w inny sposób, według innego pomysłu, $z$ udziałem innych rekwizytów. Bawienie się pozwala dziecku przedszkolnemu manipulować wyobrażeniami, „tworami abstrakcyjnymi, choć nie do końca jeszcze uwolnionymi od związków z rzeczywistością, jak w przypadku najbardziej rozwiniętych form myślenia" (Brzezińska, Appelt, Ziółkowska 2016, s. 196).

\section{ASPEKT PIĄTY - POKONYWANIE OGRANICZEŃ WŁASNYCH I OGRANICZEŃ MATERII}

Zabawa wiąże się z wysiłkiem poznawania i pokonywania ograniczeń własnych oraz ograniczeń materii, którą dziecko twórczo przekształca podczas zabawy. Janusz Korczak opisał dziecięcą zabawę w następujący sposób:

Jeśli we czworo budują szałas, kopią skrawkami blachy, szkłem, gwoździem, wbijają kołki, wiążą, pokrywają dachem z gałęzi, mchem wyściełając, pracując na przemian z wysiłkiem, milcząco [...], ale projektując ulepszenia, rozwijając dalsze plany, dzieląc się wynikami zdobytych spostrzeżeń - to nie zabawa, a nieumiejętna praca niedoskonałymi narzędziami [...], ale zorganizowana tak, że każde [dziecko - uzup. K.K.] zależnie od wieku, sił, kompetencji wkłada tyle wysiłku, na ile je stać (Korczak 2012, s. 108). 
Uzyskany w sposób indywidualny lub wspólnymi siłami efekt wywołuje uczucie zadowolenia, które wynika z tego, że „się potrafi”.

\section{ASPEKT SZÓSTY - DOKONYWANIE WYBORÓW}

Do podjęcia aktywności zabawowej przez dziecko inspiruje je „wewnętrzne chcenie" (motywacja wewnętrzna), choć (w pewnych sytuacjach) konieczne jest (np. w odniesieniu do dzieci młodszych) motywowanie zewnętrzne. Podejmując zabawę, dziecko dokonuje szeregu ważnych wyborów:

- w co się będzie bawić;

- $\quad$ z kim się będzie bawić;

- jakie rekwizyty wybrać;

- jak będzie przebiegała zabawa (co się będzie działo);

- $\quad$ w jaki sposób rozwiązać kolejno pojawiające się epizody zabawy;

- kiedy i w jaki sposób zakończyć zabawę;

- co zrobić po jej zakończeniu.

Im starsze dziecko, im więcej zgromadziło doświadczeń związanych z kreowaniem i realizowaniem własnej aktywności zabawowej, tym lepiej radzi sobie z kolejnymi wyborami, lepiej planuje zabawę, sprawniej gromadzi materiały, realizuje pomysły, wymienia się pomysłami z innymi dziećmi, włącza inne osoby do własnych działań lub modyfikuje je pod wpływem innych dzieci. W ten sposób nie tylko przyswaja określone wzorce działania, ale „przebudowuje je, włączając w obręb własnej osobowości” (Popek 1988).

\section{ASPEKT SIÓDMY - AKTYWNOŚĆ W ZESPOLE}

Zdaniem Danuty Waloszek „zabawa jest rodzajem aktywności, który umożliwia człowiekowi powolne rozpoznawanie społecznych reakcji na własną obecność w bliskości innych ludzi, na własne zachowanie w ich kontekście, rozpoznawanie stosunków, nastawień i oczekiwań innych osób” (Waloszek 2009b, s. 344). Wspomniana autorka formułuje następującą tezę: „zabawa pomaga dziecku uczyć się reagowania na zmienne parametry otoczenia, na zamianę rodzaju treści wypowiedzi, na zachowanie się adekwatne do oczekiwań (także poleceń) ze strony partnera zabawy" (Waloszek 2009b, s. 345). Wspólne bawienie się wymaga więc od dzieci poczynienia uzgodnień, podczas których dochodzi do „ustanowienia stosunków między partnerami” (Łaciak 1998, s. 90) oraz określenia wspólnych celów, zasad, które będą akceptowane i respektowane przez wszystkich uczestników wspólnej aktywności. 
Te wspólne uzgodnienia różnią się od typowych norm społecznych rządzących jawnym zachowaniem społecznym w tym, że zaczynają od konwencjonalnie stworzonej symbolicznej rzeczywistości - udawanego albo instytucjonalnego scenariusza, a następnie wspólnie nadają deontyczną moc odpowiednim rolom i bytom w ramach tego symbolicznego scenariusza (Tomasello 2016, s. 111).

W ten sposób dziecko uczy się zaspokajać nie tylko własne potrzeby i pragnienia, musi uwzględnić potrzeby, pragnienia i cele rówieśników. Warto nadmienić, że orientację dziecka na wspólne z rówieśnikiem osiąganie celu odnotowano już $\mathrm{w}$ odniesieniu do dzieci trzyletnich ${ }^{1}$. Dziecko przedszkolne znajduje się w trudniejszej sytuacji - odrzucenia przez inne dziecko lub grupę pomysłu, nieakceptacji działania, które spontanicznie podejmuje. Modyfikuje więc swoje działania zależnie od zachowań (werbalnych, niewerbalnych) współuczestników. Szuka innych sposobów prowadzących do osiągnięcia własnych celów, takich, które zostaną zaakceptowane przez towarzyszy aktywności. Uczy się takiego działania wśród innych, które przyniesie wymierny zysk w postaci kolejnego zaproszenia do zabawy lub przyjęcia przez inne dzieci propozycji wspólnego działania.

\section{PODSUMOWANIE}

Wobec powyższych argumentów dziecięcą zabawę należy przestać postrzegać jako nicnierobienie, czas wolny czy wręcz marnotrawienie czasu. W świecie pełnym zmian i sprzeczności zabawa jest dla dziecka przestrzenią, która pozwala doświadczyć stałości przy jednoczesnej możliwości dokonywania szeregu modyfikacji, zamian, próbowania, eksperymentowania. Pomaga zdobywać doświadczenia konieczne do sprostania wymogom współczesności, pozwala bowiem dziecku „poukładać sobie świat, który obserwuje i którego doświadcza”. Podstawowymi warunkami niezbędnymi, by dziecko mogło przez zabawę rozwijać niezbędne w życiu kompetencje, jest czas na zabawę, przestrzeń i swoboda działania wynikająca ze zrozumienia przez dorosłych jej ważnej roli. To przecież dorośli tworzą przestrzeń, w której dziecko żyje. Jako pośrednicy między dzieckiem a światem

${ }^{1}$ M. Tomasello opisuje następujący eksperyment, w którym uczestniczyło dwoje dzieci trzyletnich. Musiały one wspólnie przesunąć tyczkę na wyższe piętra urządzenia przypominającego schodki. Każde dziecko trzymało w dłoniach jeden koniec tyczki. Do końców tyczki przymocowane były ponadto miseczki z żetonami, które po osiągnięciu celu, dzieci mogły wymienić na nagrody. Jedno z dzieci osiągało jednak cel jako pierwsze i wcześniej mogło otrzymać nagrodę. To dziecko po odebraniu swojej nagrody, gdy zorientowało się, że jego towarzysz jej nie może uzyskać, wracało, by pomóc przetransportować tyczkę tak, by drugie dziecko mogło zamienić swój żeton na nagrodę (Tomasello 2016, s. 83). 
zewnętrznym pomagają mu zrozumieć rzeczywistość, towarzyszą dziecku, pomagają w sprostaniu wymaganiom, które stawia przed nim współczesność. Sądzę, iż nie możemy więc powiedzieć, że dzieci przestały się bawić. Może raczej zbyt mało uważnie obserwujemy je, nie dostrzegamy ich potrzeb, często je wręcz ignorujemy, nie widzimy też, co w otaczającym świecie inspiruje dzieci do aktywności zabawowej. Hamujemy podjęte próby zabawy, bo wydaje nam się, że tak się bawić nie należy. Nie zawsze chcemy dostrzec, że sami dostarczamy dzieciom inne niż kiedyś narzędzia do zabawy.

Możemy natomiast:

- w otaczającej rzeczywistości szukać inspiracji do zabawy;

- tworzyć (organizować) sytuacje, w których dziecko może się bawić;

- towarzyszyć dziecku podczas zabawy;

- współtworzyć z nim zabawę, co czyni ją dla dziecka jeszcze bardziej atrakcyjną;

- pomóc dziecku w zrozumieniu świata przez udział we wspólnej zabawie;

- podarować dziecku czas na zabawę bez pośpiechu i presji.

\section{LITERATURA}

Braun-Gałkowska M., 2008, Psychologia domowa. Lublin, Wydawnictwo KUL.

Brzezińska A. Janiszewska-Rain J., 2005, W poszukiwaniu złotego środka. Rozmowy o rozwoju człowieka. Kraków, Znak.

Buckingham D., 2008, Nowe media - nowe postaci dzieciństwa? Zmieniajace się środowisko kulturowe dzieci w erze technologii cyfrowej. W: M.J. Kehily (red.). Wprowadzenie do badań nad dzieciństwem. Kraków, WAM.

Chmurska M., Łaciak B., 2013, Małe dzieci w przestrzeni publicznej. W: B. Łaciak (red.), Dzieciństwo we współczesnej Polsce. Warszawa, Wydawnictwo Akademickie Żak. Cybal-Michalska A., 2013, Świat, w którym „kariera robi karierę”- o satysfakcji z kariery i poczuciu zawodowego sukcesu. „Studia Edukacyjne”, nr 26.

Dymara B., 2009, Żywioł i radość zabawy, czyli o zagubionych wartościach ludycznej edukacji. W: B. Dymara (red.), Dziecko w świecie zabawy. O kulturze, cechach i wartościach ludycznej edukacji. Kraków, Impuls.

Goleman D., 2014, Focus. Sztuka koncentracji jako ukryte dą̇enie do doskonałości. Poznań, Media Rodzina.

Grochowalska M., 2015, O sposobach rozumienia „dobrej” edukacji przedszkolnej z perspektywy rodziców i nauczycieli. Przykład konstruowania obrazu dzieciństwa. W: T. Parczewska (red.), Przestrzenie dziecka i dzieciństwa. Wielkość perspektyw i znaczeń. Lublin, Wydawnictwo UMCS. 
Karwowska-Struczyk M., 2007, Dzieciństwo i konteksty jego rozwoju. Warszawa, Instytut Badań Edukacyjnych.

Izdebska J., 2007, Dziecko w wiecie mediów elektronicznych. Teoria, badania, edukacja medialna. Białystok, Trans Humana.

Kantor J., 2013, Zabawa $w$ dobie społeczeństwa konsumpcyjnego. Szkice o ludyzmie, ludyczności i powadze a w istocie jej braku. Kraków, Wydawnictwo Uniwersytetu Jagiellońskiego.

Klus-Stańska D., 2011, (Anty)rozwojowa tożsamość pedagogiki wczesnej edukacji i poszukiwanie perspektyw jej rekonstrukcji. W: D. Klus-Stańska, D. Bronk, A. Malenda (red.), Pedagogika wczesnej edukacji. Dyskursy, problemy, otwarcia. Warszawa, Wydawnictwo Akademickie Żak.

Kopaczyńska I., 2010, O poczuciu sprawstwa w procesie refleksyjnego uczenia się. W: E. Jaszczyszyn, J. Szada-Borzyszkowska (red.), Edukacja dziecka: mity i fakty. Białystok, Trans Humana.

Korczak J., 2012, Jak kochać dziecko. Dziecko w rodzinie. Warszawa, Rzecznik Praw Dziecka.

Kuszak K., 2005, Dziecko samodzielnym kreatorem świata zabawy. „Wychowanie na co dzień", nr 3.

Lewartowska-Zychowicz M., 2014, Dziecko, kobieta i ubogi-genealogia (neo)liberalnego wykluczenia. „Studia Edukacyjne”, nr 33.

Łaciak B., 1998, Świat społeczny dziecka. Warszawa, Wydawnictwo Akademickie Żak. Łaciak B., 2011, Komercyjne przemiany współczesnego dzieciństwa. W: B. Łaciak (red.), Nowe społeczne wymiary dzieciństwa. Warszawa, Wydawnictwo Akademickie Żak.

Maciejewska-Mroczek E., 2012, Mrówcza zabawa. Współczesne zabawki a społeczne konstruowanie dzieciństwa. Kraków, Universitas.

Męczkowska-Christianse A., 2011, Dyskursy dzieciństwa a polityka. Pomiędzy wykluczeniem a obywatelskim uczestnictwem. W: D. Klus-Stańska, D. Bronk, A. Malenda (red.), Pedagogika wczesnej edukacji. Dyskursy, problemy, otwarcia. Warszawa, Wydawnictwo Akademickie Żak.

Melosik Z., 2013, Kultura popularna i tożsamość młodzieży. Kraków, Impuls.

Michałowska D.A., 2013, Neoliberalizm i jego (nie)etyczne implikacje edukacyjne. Poznań, UAM.

Nyczaj-Drąg M., 2015, Edukacja dziecka w narracjach rodziców klasy średniej. Zielona Góra, Uniwersytet Zielonogórski.

Olczak A., 2014, W labiryncie dziecięcych potrzeb i nauczycielskich oczekiwań-krótka historia jednego dnia w przedszkolu. W: M. Magda-Adamowicz, A. Olczak (red.), Pedagogika przedszkolna. Oblicza i poszukiwania. Toruń, Adam Marszałek.

Popek S., 1988, Psychoterapeutyczna funkcja dziecięcej ekspresji artystycznej. W: S. Popek (red.), Twórczość artystyczna w wychowaniu dzieci i młodzieży. Warszawa, WSIP. 
Potulicka E., 2014, Neoliberalne reformy edukacji w Stanach Zjednoczonych. Kraków, Impuls.

Potulicka E., Edukacja przeciw neoliberalnym „wartościom” i polityce oświatowej, opublikowano: http://www.tnszp.pl/index.php/polityka-owiatowa/990-edukacjaprzeciw-neoliberalnymwartosciom-i-polityce-oswiatowej [dostęp: 28.12.2015].

Rutkowiak J., 2012, Jak kształtować kulturę zaufania i odpowiedzialności w szkole w warunkach promowania rywalizacji przez neoliberalizm? „Studia Edukacyjne”, nr 22. Segiet W., 2011, Rodzina a edukacja dziecka. Tradycyjne ujęcia i nowe trendy. W: A. Cybal-Michalska., D. Kopeć, W. Segiet (red.), Studia z pedagogiki i nauk pogranicza. Poznań, UAM.

Śliwerski B., 2005, Współczesne teorie i nurty wychowania. Kraków, Impuls.

Śliwerski B., 2014, Dziecko jako niepożądany obiekt autokratycznych przemian. W: M. Magda-Adamowicz, A. Olczak (red.), Pedagogika przedszkolna. Oblicza i poszukiwania. Toruń, Wydawnictwo A. Marszałek.

Świetlik M., 2009, Nowa przestrzeń dziecka we współczesnej kulturze, W: B. Łaciak (red.), Dziecko we współczesnej kulturze medialnej. Warszawa, Instytut Spraw Publicznych.

Szlendak T., 2011, Socjologia rodziny. Ewolucja, historia, zróżnicowanie. Warszawa, PWN.

Tomasello M., 2016, Dlaczego współpracujemy. Kraków, Copernicus Center Press.

Waloszek D., 2006, Pedagogika przedszkolna. Metamorfoza statusu i przedmiotu badań. Kraków, Wydawnictwo Naukowe Akademii Pedagogicznej.

Waloszek D., 2009, Zawłaszczanie dzieciństwa. XXI wiek. Etiologia zjawiska. W: I. Izdebska., J. Szymanowska (red.), Dziecko w zmieniającej się przestrzeni życia. Obrazy dzieciństwa. Białystok, Trans Humana.

Waloszek D., 2009, Socjopedagogiczny wymiar zabawy w edukacji wczesnoszkolnej. W: D. Klus-Stańska, M. Szczepska-Pustkowska (red.), Pedagogika wczesnoszkolnadyskursy, problemy, rozwiązania. Warszawa, Wydawnictwa Szkolne i Akademickie.

Winnicot D.W.. 1993, Dziecko, jego rodzina i świat. Warszawa, Jacek Santorski \& CO Agencja Wydawnicza.

Wygotski L., 2002, Zabawa i jej rola w rozwoju psychicznym dziecka. W: A. Brzezińska, M. Marchow (red.), Wybrane prace psychologiczne. Dzieciństwo i młodość. Poznań, Zysk i S-ka. 


\title{
A PRESCHOOL CHILD: BETWEEN REALITY, EXPECTATIONS
}

\section{AND THE NEED FOR UNINHIBITED PLAY}

\begin{abstract}
The article analyses the contemporary neoliberal reality and educational practices used in preschool education as well as contradicting expectations held of preschool children. It starts with a general description of neoliberalism as a set of practices, a discourse and a worldview which influences all spheres of contemporary people's functioning. The author proceeds to summarize the neoliberal discourse on childhood. She presents the following images of childhood formulated within its framework: childhood as an investment, childhood inscribed within a procedure, childhood characterized by a shortage of time, virtual childhood, and commercial childhood. These discourses and the consequent practices clash with expectations held of children. The article points out the following expectations to which children are held: ability to manage their own time, agency and independence, focus and attentiveness, ability to select offers and make a choice. The author attempts to view children's play as a form of investment into good quality childhood. She points out selected elements of play, which through their spontaneity allow the individual to develop traits and skills desired by the contemporary society. The final part offers guidelines for educational practice, where the author indicates opportunities to create situations when children can play and adults can accompany them in the play, create the play together with children, etc. She underlines the role of adults in organising opportunities for play free from hurry and time pressure.
\end{abstract}

Keywords: neoliberalism, preschool child, expectations held of children, play 